\title{
The Shadow Lines as a Post Modern Novel
}

\author{
P. Pradeep \\ Sreenidhi Institute of Science and Technology, Ghatkesar, India \\ Acharya Nagarjuna University, Guntur, India
}

\author{
R. Poli Reddy \\ SV Arts \& Science College, Giddaluru, India \\ Acharya Nagarjuna University, Guntur, India
}

\begin{abstract}
Amitav Ghosh is one the most remarkable writers of the postmodernism era. He excelled in this era with his trend of magic realism. The Shadow Lines is a story told by a nameless narrator in recollection. It's a non linear tale told as if putting together the pieces of a jigsaw puzzle in the memory of the narrator. This style of writing is both unique and captivating; unfolding ideas together as time and space coalesce and helping the narrator understand his past better. Revolving around the theme of nationalism in an increasingly globalized world, Ghosh questions the real meaning of political freedom and the borders which virtually seem to both establish and separate. The novel traverses through almost seventy years through the memories of people, which the narrator recollects and narrates, giving their viewpoint along with his own. Though the novel is based largely in Kolkata, Dhaka, and London, it seems to echo the sentiments of whole Southeast Asia, with lucid overtones of Independence and the pangs of Partition.
\end{abstract}

Keywords: postmodernism, magic realism, blend of themes, unique style of narration

\section{Introduction}

Oxford Advanced Learner's Dictionary defined post modernism as a style and movement in art, architecture, literature etc., in the late 20th century that reacts against modern styles, for example by mixing features from traditional and modern styles. Having taken the meaning of Oxford Advanced Learner's Dictionary into consideration, I can say that the novel The Shadow Lines falls under the genre of post-modernism. I would like to discuss some of the most striking themes of The Shadow Lines.

\section{Theme of Nostalgia}

It is obviously true from the point of view of both the characters-Thamma i.e., the grandmother of the narrator and the old man, Jethamoshai, Thamma's uncle.

It is the love towards their homeland or country that stopped them to move away from their lands at any moment. Though Thamma lost her husband, she did not move anywhere in search of her livelihood. She wanted to take her last breath only on the land where she was born. That is why she criticizes Ila saying,

Ila has no right to live there. She does n't belong there. It took those people a long time to build that country; hundreds of years, years and years of war and bloodshed. Everyone who lives there has earned his or her right to be there with blood; with their brother's blood and their father's blood and their son's blood. They know they are a nation because

P. Pradeep, Ph.D., Research Scholar at Acharya Nagarjuna University, Assistant Professor at Sreenidhi Institute of Science and Technology, Yamnampet, Ghatkesar, Ranga Reddy District, Telangana State, India.

R. Poli Reddy, Principal at SV Arts \& Science College, Research Superviser at Acharya Nagarjuna University, Guntur, Andhra Pradesh State, India. 
they have drawn their borders with blood. War is their (The British) religion. That's what it takes to make a country. Once that happens people forget they were born this or that, Muslim or Hindu, Bengali or Punjabi; they become a family born of the same pool of blood. (Ghosh, 1988, p. 95)

Coming to the old man, Jethamoshai, he is a stubborn. In fact, he is a lawyer by profession. Though he was weak physically, mentally too strong. He had a great sense of loyalty and devotion towards his mother land. It was very evident from his talks with Thamma and Mayadebi when they visited Bangladesh to get him back to Kolkata where they were living. He protested straightly. In his own words, I know everything, I understand everything. Once you start moving you never stop. That's what I told my sons when they took trains. I said,

I don't believe in this India-Sindhia. It's all very well you are going away now, but suppose when you get there they decide to draw another line somewhere? What will you do then? Where will you move to? No one will have to move anywhere? As for me, I was born here, and I will die here. (personal communication)

\section{Theme of Nationalism}

Ghosh portrayed the quest for the freedom from the British through the characters of Thamma and her classmate in school, the shy boy who had joined as a member of one of the secret terrorist societies since he was fourteen. He had given a mission to assassinate an English magistrate in Khulna district. When he was about to leave on his mission, he had been caught by the police. Then the whole class felt aghast. In fact, He had taken this not for his personal profit. He committed to die for the freedom of India.

At the very moment, even Thamma was fascinated towards his deeds. She would have been content to run errands for them, to cook their food, wash their clothes, anything. It was for the glory of the nation. She did not know how to set in touch with them and even if she had it would have been twice as hard for her to get in, because she was a girl, a woman.

Thamma even speaks about war declared with Pakistan in 1965. She is standing with her hair hanging in wet ropes over her face, eyes glazed, spectacles fallen off, smashing the glass front of the radio and gouging out flesh and blood against it. "We're fighting them at last, with tanks and guns and bombs" (Ghosh, 2000, p. 238), she says hysterically.

\section{As a Historical Novel}

It is no wrong to call The Shadow Lines as a historical novel as it is closely associated to the historical events i.e., to the modern history of India and also some of the incidents of the world history, especially the portrayal of the World War II is very clear through the words of the narrator. He said to Ila,

when we came out of the tube station I stopped them and pointed down the road. Since this is west lane, I said, that must be Sumatra road over there. So that corner must be where the air raid shelter was, the same one that Robi's mother and your mother and your uncle Alan ducked into on their way back from mill lane, when one of those huge high caliber bombs exploded on silent road, around the corner, blowing up most of the houses there. And that house, that one, just down the road, over there, on the corner of Lymington road, I know what it's called Lymington mansions, and an incendiary bomb fell on it, and burned down two floors. That was on the 1st of October 1940, two days before your uncle died. (Ghosh, 1988, p. 85)

This novel mentioned the World War II (1939-1945) and India-China War (1962), India-Pakistan War (1965) and Communal Riots (1964). 


\section{Theme of Violence}

Violence is one of the most striking themes in the novel The Shadow Lines. Violence is described regarding the death of his inspirer and role modal i.e., Tridib. He said, "I can only describe at second hand the manner of Tridib's death: I do not have the words to give it meaning. I do not have the words, and I do not have the strength to listen" (Ghosh, 1988, p. 251).

He also described the scenario of Calcutta that time. In Calcutta rumours were in the air, especially that familiar old rumour, the harbinger of every serious riot that the trains from Pakistan were arriving packed with corpses. A few Calcutta dailies printed pictures of weeping, stranded Hindu refugees, along with a few lurid accounts of the events in the East. On 8 and 9 January, with refugees still pouring in, rumours began to flow like floods through the city and angry crowds began to gather at the stations. Mobs went rampaging through the city, killing Muslims, and burning and looting their shops and houses.

\section{Theme of Partition of the Joint Family}

The narrator describes how his family lived under the same roof and how they divided is clearly portrayed. He said, "It was a very odd house. It had evolved slowly, growing like a honeycomb, with every generation of Boses adding layers inhabited by so many branches of the family that even the most knowledgeable amongst them had become a little confused about their relationships” (Bose, 2003, p. 19).

Their own part of the house was quite large and, in my grand mother's earliest memory, it was very crowded. Theirs was a big joint family then, with every one living and eating together: her grandparents, her parents, she and Mayadebi, her Jethamoshai-her father's elder brother—and his family, which included three cousins of roughly her own age, as well as a couple of spinster aunts. She remembered her grandfather, although she had been six when he died: a thin, stern looking man with a frown etched permanently into his forehead. In his presence, everyone, including her father and Jethamoshai, spoke in whispers, with their heads down and their fixed firmly on the floor. But when he left the house for the district courts, where he practiced as an advocate, the house would erupt with the noisy games of the five cousins. Every evening the five children would be led by their mothers into his study, where they would each have to recite their alphabets—Bengali first and then English, with their hands held out, palm downwards, and he would rap them on the knuckles with the handle of the umbrella every time they made a mistake. If they cried they were rapped on their shins.

Though he was still terrifying, he did manage to keep the house together. After he died, Jethamoshai, as their eldest son, tried hard to step into his place, but without success. He was an odd man, Jethamoshai; in some ways he was an oddly lovable man, but in others he was even more frightening than his father. He was thinner for one, cadaverous in fact, and he had very bright and piercing eyes, set deep in the hollows of his long, gaunt face. But he had had odd notions — he liked to eat standing up, for instance, because he thought it was better for the digestion: No animal has a better digestive system than the cow; he used to say, and look at them when they eat standing up. He was undeniably eccentric and the children found it hard to take him altogether seriously. For example, after his father died, he insisted that the children recite the alphabet every morning to him too, while he sat exactly as his father had, with the handle of his umbrella poised over their knuckles. But although he looked eerie bit as stern as his father, he had had an odd trick of blowing through his lips, exactly like a tired Tonga-horse, when he was listening. So, often, either she or Mayadebi would burst into laughter, half way through their recitation. Often, after he had lost temper, he would secretly buy the children halwa and shandesh 
as a kind of apology. But their mother did not know this, and with in a month or so of her father-in-law's death, she was no longer on speaking terms with Jethamoshai and his wife and family.

It did not take long for the quarrels to get worse. The two women began to suspect each other of favouring their own children above the rest, of purloining the best little tidbits of food for them from the common ladder and so on.

Soon things came to such a pass that they decided to divide the house with a wooden partition wall: There was no other alternative. But the buildings of the wall proved to be far from easy because the two brothers, insisting on their rights with a lawyers like precision, demanded that the division be exact down to the minutest detail. Even the wall was eventually built, they found that it had ploughed right through a couple of doorways so that no one could get through them anymore; it had also gone through a lavatory bisecting an old commode. The brothers even partitioned their father's old nameplate. It was divided down the middle by a thin white line, and their names were inscribed on the two halves-of necessity in letters so tiny that nobody could read them.

\section{As an Ironical Novel}

The novel The Shadow Lines can also be said as an irony. As Mayadebi and Thamma went to Bangladesh to bring the old man, Jethamoshai to unite him with their family from Shakil's house. At the same time, as they were returning to meet their family, Shakil and Tridib died in the hands of a Muslim mob cruelly. They expected one but faced another one i.e., death. So we can say that is a novel dealing with an irony.

\section{Theme of Immigration}

This is another major striking theme of post-modernism. This novel particularly deals with the migration of the narrator's family to different parts of the world.

The very opening line of the novel describes the migration of his family in 1939, thirteen years before I was born. My father's aunt, Maya Debi, went to England with her husband and her son, Tridib.

Her elder son, Jatin-kakle, who was 20 years older than Tridib, was an economist with the U.N. He was always away too, somewhere in Africa or South East Asia, with his wife and daughter, Ila.

Tridib is the second one. The third brother, Robi, who was much younger than the other two, having been born after his mother had miscarriages, lived with his parents wherever they happened to be posted until he was sent to boarding school at the age of twelve.

There was also a kind of criticism in the novel regarding the migration of Ila towards alien land. Narrator's grandmother told narrator, “Shall I tell you what Ila is gone for?” (Ghosh, 1988, p. 112).

She is gone there because she is greedy; she is gone there for money, he replied. She said, it's not for money. It's a thing: it's all things money can buy, fridges like the one Mrs. Sen's son-in-law brought back from America, with two doors and a spout that drops ice-cubes into your glass; colour TVs and Cars, calculators and cameras all things you can't get here.

\section{As a Novel of Fact and Fiction}

This is a novel of both fact and fiction. The author, Amitav Ghosh, he himself declared it clearly in hid foreword: "This is a work of fiction. Names, characters, places and incidents are either the product of the author's imagination or are used fictitiously and any resemblance to any actual person, living or dead, events or locales is entirely coincidental" (Ghosh, 1988, foreword). 
In an interview, Ghosh defined his choice of fiction over history:

I think fiction has always played that part. If you look at Tolstoy’s War and Peace... I think the difference between the history historians write and the history fiction writers write is that fiction writers write about the human history. It's about finding human predicament, it's about finding what happens to individuals, characters. I mean that's what fiction is ...Exploring both dimensions, where as history, the kind of history exploring causes, causality, is of no interest to me. ${ }^{1}$

Saying that he woovened the history with the realities of the past i.e., the history of India in an ironical way. He focused on the incidents like World War II, the partition of India, Indo-China War, Indo-Pak War and Communal Riots that shook Calcutta.

He did magic with the reality. So we can rightly call it a Magical Realism.

\section{As a Criticism Against Communal Differences}

Through this novel, The Shadow Lines, Ghosh declared that humanity is more important than community through his narrator of this story. He said, “on 10th January, the army was called out of Fort William fort and several battalions were deployed through out the city. There are no reliable estimates of how many people were killed in the riots of 1964" (Bose, 2003, p. 12).

The university communities of both Dhaka and Calcutta took the initiative in doing relief work and organizing peace marches and news papers on both sides of the border that did some fine, human pieces of reporting. As always, there were innumerable cases of Muslims in East Pakistan giving shelter to Hindus, often at the cost of their own lives, and equally, India, of Hindus sheltering Muslims. But they were ordinary people, soon forgotten—not for them any martyr's memorials or Eternal flames.

At another occasion Ghosh criticized the practice of communal difference through the talks of Narrator's grandmother and Saifuddin, a mechanic from Bengal settled in Dhaka. She asked Saifuddin, "does Khalil's wife cook for him too?”

"Of course", said Saifuddin. "If she did n't cook, the old man would n't get anything to eat".

She exchanged a look of amazement with Mayadebi. "Do you know? She whispered to Robi. There was a time when that old man was so orthodox that he would n't let a Muslim's shadow pass within ten feet of his food? And look at him now, paying for the price of his sins” (Ghosh, 1988, p. 231).

\section{As a Novel Depicting the Cultural Identity (Unity in Diversity)}

Through this novel, The Shadow Lines, Ghosh portrayed the cultural identity of India through the festivals and festivities. He described the festival of the relic.

There was a relic known as Mu-i-Mubarak believed to be hair of the prophet Mohammad himself-was purchased by a Kashmiri merchant called Khwaja Nur-Ud-din in Bijapur (near Hyderabad) in the year 1699. The following year the sacred relic was transported to the valley of Kashmir. This is only one version of the provenance of the relic; there are several others. It is agreed, however, that the arrival of the relic was greeted by a great tumult of joy in the valley. People are said to have marched in there thousands from every part of Kashmir, even from such district and remote eyeries as the Banial Pass, in order to get a glimpse of the relic. Later, the relic was installed at the picturesque Hazratbal Mosque near Srinagar. This mosque became a great centre of pilgrimage and every year multitude of people, Kashmiris of every kind, Muslims, Hindus, Sikhs, and

${ }^{1}$ Amitav Ghosh (September 30, 2000), in “Shadow Script”, an interview to First City, New Delhi. 
Buddhists, would flock to Hazratbal on these occasions when the relic was displayed to the public. Thus, over the centuries, the shrine became the symbol of the unique and distinctive culture of Kashmir.

On 27 December, 1963, two hundred and sixty years after it had been brought to Kashmir, the Mu-i-Mubarak disappeared from its place in the Hazratbal mosque. Then it created a lot of disturbance in the Kashmir. All people wore black dress and conducted hartals, even took part in Bundh. They observed 31st December as a Black Day and soon other cities followed suit. Irrespective of the caste, colour, creed, and community, all Kashmiris took part in this hartal. It is the unity of Indian culture in Diversity.

But, of course, the Mu-i-Mubarak was restored on 4th January by the officials of CBI. There were no explanations; indeed, to this day nobody really knows what happened to Mu-I-Mubarak.

\section{As a Novel Dealing With the Border Issues}

This novel, The Shadow Lines, shows the plight of the narrator's grandmother and her loss of the sense of secure moorings; a point of reference to which one returns for assurance. Her loss was caused due to the borders imposed on her. Thamma would have been perplexed with Muir's elegantly defined boundaries that only existed in the conceptual space. In her own simple way, she

wanted to know whether she was able to watch the lines drawn as borders while going in or not. One of the many appealing facets of TSL is the way it looks at the accident that descended on the pages of history: the creation of two nations on the basis of the incompatibility of two religious groups and their mutual hatred. East and West Pakistan were carved out of the British India on the basis of the two nation theory that totally opposed any possibility of co-existence. Boundaries were created and people were forced to alter their lives and selves to accommodate them to the conceptual nations that the powerful persons had created would be able to see the border between India and East Pakistan from the plane. (Ghosh, 1988, p. 90)

She wasn't looking for a line as such, but for some indicator of demarcation.

Her son gave her complete idea regarding these lines saying that you won't find anything. Then she doubts, but if there are no trenches or anything, how could people know? I mean where is the difference then? And if there is no difference both sides will be the same, it will be just like it used to be before, when we used catch a train in Dhaka and get off in Calcutta the next day without anybody stopping us.

Then her son retorted in exasperation. It's not as though you are flying over the Himalayas into China. This is the modern world. The border is not on the frontier: it is right inside the air port. You will see. You will cross it when you have to fill in all those cards and things. They want your nationality, your date of birth, place of birth, that kind of thing.

For Ghosh borders are self reflexive frames for constructing meaning "shadow lines", which acquire an interstitial intimacy that transgresses the monologue fixity of nationalist boundaries. Only when the narrator comes to understand that the boundary is that line where the shadow of the other falls upon the self and it is here that the novel's title resonates with meaning can he arrive at a fuller understanding of his complex identity as a subject of the postcolonial Indian nation.

\section{Theme of the Displacement of Time}

In The Shadow Lines, the world of war torn London is overlaid by the memories of Calcutta and Dhaka. Letting his stories interplay with time, Ghosh achieves an unusual synthesis of time. Though it is about London and Dhaka, it is applicable to very one on the earth. 
We can see this relationship of the social to a concept of inner-speech in the text of The Shadow Lines in a comment that the nameless narrator states in relation to the other characters desires for an autonomy from the social. "I began to wonder whether it was I that was mad because I was happy to be bound: whether I was alone in knowing that I could not live without the clamor of voices within me” (Dhawan, 1999, p. 80). The unique characteristic of the protagonist and his hero Tridib is that they produce their sense of self within these structures, structures that are in some ways unbreakable. After all, the notions of autonomy and the separation desired by Ila and the grandmother are just other forms of collectivity, forms that reproduce the society as it is.

This novel runs observing two different times and places, two different realities, imaginary (memory) and real (present perception) and experiences a merging very much like the one the narrator experiences in the cellar.

\section{Justification of the Title}

As per my opinion, the title, "The Shadow Lines" is apt to this novel as it deals with the lines drawn between the families and countries. Though many centuries passed after getting the independence, though we are free from the clutches of colonialism, though we are born in a democratic and secular country, still we can observe many lines drawn among the persons to separate individuals in the name of caste, colour, creed, community, gender, and region etc.

\section{Conclusion}

Here with I would like to conclude with the opinion, this is a novel consisting typically modernist problems of the dissociation of essence and appearance is solved in The Shadow Lines through the construction of a typically postmodern spatial vision. Realities that "stem from different zones of time or from unrelated compartments of the social and material universe" have been united and a "mode of perception" has been achieved, which seems to operate by way of the simultaneous preservation of...incompatibles, a kind of incommensurability-vision that does not pull the eyes back to focus but provisionally entertains the tension of their multiple coordinates. These "multiple coordinates" of the cellar are the imaginary and the actual, and the past and the present.

\section{References}

Amitav Ghosh. (n.d.). Retrieved from http://www.amitavghosh.com/ Arundathi, R. (1997). The God small things. London: Flamingo.

Bhaba, H. J. (Ed.). (1990). Nation and narration. London: Routledge.

Bhatt, I., \& Nityanandam, I. (2001). The fiction of Amitav Ghosh. New Delhi: Creative Books.

Bose, B. (2003). Amitav Ghosh: Critical perspectives. New Delhi: Pencraft International.

Dhawan, R. K. (1999). Novels of Amitav Ghosh. New York: Prestige Books.

Ghosh, A. (1988). The shadow lines. New Delhi: Penguin Books, Ravi Dayal Publishers.

Nehru, J. (1951). The discovery of India. London: Meridian Books. 